\title{
Natriuretic Peptides Inhibit Angiotensin II-induced Proliferation of Rat Cardiac Fibroblasts by Blocking Endothelin-1 Gene Expression
}

Hiroyuki Fujisaki, Hiroshi Ito, * Yukio Hirata, Masato Tanaka, Mimi Hata, Meihong Lin, Susumu Adachi, Hajime Akimoto, Fumiaki Marumo, and Michiaki Hiroe

The Second Department of Internal Medicine, Tokyo Medical \& Dental University, Tokyo, Japan

\begin{abstract}
The present study was aimed to test the role of endothelin1 (ET-1) as a possible autocrine/paracrine growth factor for cardiac fibroblasts, and to examine its interaction with cardiac natriuretic hormones. Expression of preproET-1 (ppET-1) mRNA by cultured cardiac fibroblasts from neonatal rats was demonstrated by Northern blot analysis using cDNA for rat ppET-1 as a probe. Angiotensin II (ANG II) and ET-1 transiently ( $30 \mathrm{~min}$ ) increased steady-state ppET1 mRNA levels in cardiac fibroblasts. Both ET-1 and ANG II significantly stimulated $\left[{ }^{3} \mathrm{H}\right]$ thymidine incorporation into cardiac fibroblasts, whose effects were dose-dependently inhibited by an $\mathrm{ET}_{\mathrm{A}}$ receptor antagonist $(\mathrm{BQ123}) . \mathrm{BQ123}$ also inhibited both ET-1- and ANG II-induced ppET-1 mRNA expression. Both atrial and brain natriuretic peptides (ANP, BNP), which activate particulate guanylate cyclase, inhibited ppET-1 mRNA expression and $\left[{ }^{3} \mathrm{H}\right]$ thymidine incorporation stimulated by ANG II and ET-1. Sodium nitroprusside, a soluble guanylate cyclase activator, and 8-bromocyclic GMP, a membrane-permeable cGMP derivative, similarly inhibited ppET-1 mRNA expression and $\left[{ }^{3} \mathrm{H}\right]-$ thymidine incorporation. BNP was more potent than ANP to inhibit ANG II- and ET-1-stimulated DNA synthesis, whereas BNP and ANP were almost equipotent in stimulating cGMP generation in cardiac fibroblasts. Our data demonstrated that ANG II and ET-1 upregulate ET-1 gene expression in rat cardiac fibroblasts partly via cyclic GMPdependent mechanism, and that natriuretic peptides inhibit ANG II-stimulated proliferation of cardiac fibroblasts, possibly by inhibiting ET-1 gene expression. Our data suggest the possible role of endogenous ET-1 as an autocrine/paracrine growth factor for cardiac fibroblasts and its close interaction with natriuretic peptides in the regulation of cardiac fibrosis. (J. Clin. Invest. 1995. 96:1059-1065.) Key words: ANP • BNP • BQ123 • mRNA • thymidine incorporation
\end{abstract}

Address correspondence to Hiroshi Ito, M.D., The Second Department of Internal Medicine, Tokyo Medical \& Dental University, 1-5-45 Yushima, Bunkyo-ku, Tokyo, 113 Japan. Phone: 3 3813-6111, FAX: 3 3818-7177.

Received for publication 12 May 1994 and accepted in revised form 10 April 1995.

J. Clin. Invest.

(C) The American Society for Clinical Investigation, Inc.

0021-9738/95/08/1059/07 \$2.00

Volume 96, August 1995, 1059-1065

\section{Introduction}

Although cardiomyocytes occupy $\sim 75 \%$ of the structural space of the heart, they constitute only one third of the total cell population $(1,2)$. The remaining non-myocytes consist mainly of cardiac fibroblasts in the interstitium. It has been recently shown that growth of cardiac fibroblast associated with enhanced collagen accumulation in the myocardial interstitium is involved in the remodeling process of left ventricular hypertrophy $(3,4)$.

Several recent in vivo studies have suggested that angioten$\sin$ II (ANG II) ${ }^{1}$ is a critical growth factor for cardiac hypertrophy. Treatment with a subdepressor dose of angiotensin-converting enzyme inhibitors (5) and angiotensin receptor antagonists (6) prevent an increase in left ventricular mass. It has been also reported that chronic infusion of a subpressor dose of ANG II into rats causes left ventricular hypertrophy(6). Since ANG II stimulates cellular proliferation (7) and several extracellular matrix gene expressions in cardiac fibroblasts (8), and induces cardiomyocyte hypertrophy $(9,10)$, ANG II is considered to act directly on both cardiomyocytes and fibroblasts.

We (11) and other investigators $(12,13)$ have previously demonstrated that endothelin-1 (ET-1) induces cardiomyocyte hypertrophy in vitro. Recently, we have further shown that cultured rat cardiomyocytes express abundant preproET-1 (ppET1) transcripts and release mature ET-1 into medium (14), and that cardiomyocyte hypertrophy stimulated by ANG II is partially blocked by a receptor antagonist selective for $\mathrm{ET}_{\mathrm{A}}$ subtype (14). These in vitro observations led us to speculate that endogenous ET-1 in cardiomyocytes induced after initial activation of ANG II may be an autocrine/paracrine growth factor for cardiomyocytes. While a direct growth effect of ANG II on cardiac fibroblasts has been well established $(7,8)$, subsequent signaling pathways following initial stimulation by ANG II remained unknown.

Natriuretic peptide family consists of atrial natriuretic peptide (ANP), brain natriuretic peptide (BNP) and C-type natriuretic peptide (CNP) (15). Both ANP and BNP are cardiac hormone mainly secreted from atria and ventricles, respectively, while CNP is a neuropeptide. It has been reported that ANP and BNP inhibit proliferation and/or hypertrophy of rat vascular smooth muscle cells and endothelial cells (16). Furthermore, ANP and BNP have been shown to inhibit biosynthesis and

1. Abbreviations used in this paper: 8-bromo-cGMP, 8-bromoguanosine 3',5' cyclic monophosphate; ANG II, angiotensin II; ANP, atrial natriuretic peptide; Ara C, cytosine arabinoside; BNP, brain natriuretic peptide; CNP, C-type natriuretic peptide; ET-1, endothelin-1; GAPDH, glyceraldehyde-3-phosphate dehydrogenase; IBMX, methylisobutylxanthine. 
release of ET-1 from cultured rat endothelial cells (17). Since ANP and BNP are synthesized by and secreted from cardiomyocytes located very close to fibroblasts, we have hypothesized that natriuretic peptides may exert growth-inhibitory effect on cardiac fibroblasts and affect ET-1 gene expression by cardiac fibroblasts.

Therefore, the present study was designed to investigate (1) whether ANG II upregulates ppET-1 gene expression in cardiac fibroblasts, (2) whether endogenous ET-1 mediates the proliferation of cardiac fibroblasts via $\mathrm{ET}_{\mathrm{A}}$ receptor subtype, and (3) whether natriuretic peptides affect ppET-1 gene expression and proliferation of cardiac fibroblasts stimulated by ANG II.

\section{Methods}

Drugs and cDNAs. The following drugs were used; synthetic ET-1, ANG II, rat ANP (1-28) and rat BNP (1-35) (Peptide Institute, Osaka, Japan), sodium nitroprusside (SNP), 8-bromoguanosine $3^{\prime}, 5^{\prime}$ cyclic monophosphate (8-bromo-cGMP) and IBMX (3-isobutyl-1-methylxanthine) (Sigma Chemical Co., St. Louis, MO), deoxycytidine 5 '- $[\alpha-$ $\left.{ }^{32} \mathrm{P}\right]$ triphosphate and $\left[{ }^{3} \mathrm{H}\right]$ thymidine, (Amersham Japan, Tokyo). BQ123 (18) was provided by Banyu Pharmaceutical Co. Ltd. (Tokyo, Japan). Rat preproendothelin-1 (ppET-1) and glyceraldehyde-3-phosphate dehydrogenase (GAPDH) cDNAs were generously provided by Dr. T. Masaki (Kyoto University, Japan) and Dr. K. Webster (SRI International, Menlo Park, CA), respectively. $c$-fos cDNA was supplied from Japanese Cancer Research Bank (Tokyo, Japan).

Cell culture and treatment. Primary cultures of neonatal rat cardiac fibroblasts were prepared as previously described (19). Briefly, the ventricles from 1- or 2-d-old neonatal Wistar rats (Japan Laboratory Animals, Tokyo, Japan) were minced and dissociated with $0.1 \%$ collagenase (Sigma Chemical Co.). Dispersed cells were incubated on 100 $\mathrm{mm}$ culture dishes (Falcon, Oxnard, CA) for $30 \mathrm{~min}$ at $37^{\circ} \mathrm{C}$ in $5 \%$ $\mathrm{CO}_{2}$ incubator, and non-myocytes attached to the dish floor were subsequently incubated with minimum essential medium (MEM) supplemented with $10 \%$ fetal calf serum, $1 \mathrm{mg} / \mathrm{ml}$ insulin and $5 \mathrm{mg} / \mathrm{ml}$ transferrin. 2-4 d after seeding, confluent non-myocytes were trypsinized and subcultured. Subconfluent ( $\sim 70 \%$ confluency) cardiac fibroblasts from the second to fourth passage were used for the experiments. $2 \mathrm{~h}$ after serum deprivation, cultures were pretreated with test compounds (ANP, BNP, cGMP, SNP, BQ123) for $2 \mathrm{~h}$, followed by treatment with ANG II or ET-1 under a serum-free conditions for the indicated times.

Immunocytochemistry. Immunocytochemical study using rabbit anti-human Factor-VIII, and anti-human $\alpha$-actin and anti-human vimentin antibody (Dakopatts. Glostrup, Denmark), was performed by the avidin-biotin-peroxidase complex $(\mathrm{ABC})$ method using a Vectastain ABC Kit (Vector Laboratories, Burlingame, CA). Cardiac fibroblasts plated on Tissue Culture Chambers (Nunc Inc. Roskilde, Denmark) were fixed in $4 \%$ paraformaldehyde. After blocking intrinsic peroxidase activity with $0.3 \% \mathrm{H}_{2} \mathrm{O}_{2}$ in methanol for $30 \mathrm{~min}$, cells were preincubated with $5 \%$ of normal goat serum for 30 minutes and incubated with primary antibodies diluted to 1:40 (factor VIII, $\alpha$-actin) or 1:100 (vimentin) in phosphate-buffered saline (PBS) with $1 \%$ bovine serum albumin overnight at $4^{\circ} \mathrm{C}$. After washing three times with PBS, the cells were incubated with biotin-conjugated anti-rabbit IgG for $2 \mathrm{~h}$ at room temperature. Peroxidase was visualized using the chromogen 3,3'-diaminobenzidine and $\mathrm{H}_{2} \mathrm{O}_{2}$. Counterstaining was performed with hematoxylin. Rat aortic endothelial cells and rat cardiomyocytes were used as positive controls for staining with antibodies for factor VIII and $\alpha$-actin, respectively.

Northern blot analysis. Northern blot analysis of rat ppET-1 mRNA was performed as reported (14). In brief, total RNA from neonatal rat cardiac fibroblasts was isolated in guanidine thiocyanate and centrifuged through $5.7 \mathrm{M} \mathrm{CsCl}$ cushion (20) RNA was size-fractionated through a $1.4 \%$ agarose gel in $0.7 \mathrm{M}$ formaldehyde and $20 \mathrm{mM}$ morpholinopro- panesulfonic acid/5 mM sodium acetate/1 mM EDTA. Northern blot hybridization was performed with hybridization buffer containing $50 \%$ formamide, $5 \times$ Denhardt's solution, $100 \mathrm{mg} / \mathrm{ml}$ salmon sperm DNA, and $5 \times \operatorname{SSPE}(0.75 \mathrm{M} \mathrm{NaCl} / 0.05 \mathrm{M} \mathrm{NaH} 2 \mathrm{PO} 4 / 0.005 \mathrm{M}$ EDTA $) .{ }^{32} \mathrm{P}$ labeled cDNA probes were prepared by the random primer method (21). The membranes (Magnagraph Nylon; Micron Separations Inc., Westborough, MA) were washed twice with $5 \times$ SSPE $/ 10 \%$ sodium dodecyl sulfate (SDS) at room temperature, twice with $1 \times$ SSPE $/ 10 \%$ SDS, and once with $0.1 \times \mathrm{SSPE} / 10 \%$ SDS at $60^{\circ} \mathrm{C}$ for $15 \mathrm{~min}$ each. Autoradiography was performed on Fuji RX film with an intensifying screen at $-80^{\circ} \mathrm{C}$. Radioactivities of the corresponding bands on Northern membrane were quantified by an image analyzer system (BAS 2000; Fuji Film Corp, Tokyo, Japan). Results were normalized by GAPDH signals. Statistical analyses were performed using quantitative data from four independent Northern experiments.

$\left[{ }^{3} \mathrm{H}\right]$ Thymidine incorporation. DNA synthesis was evaluated by incorporation of $\left[{ }^{3} \mathrm{H}\right]$ thymidine into cells. After pretreatment with test compounds for $2 \mathrm{~h}$, cardiac fibroblasts $\left(2 \times 10^{5}\right.$ cells) were incubated with ANG II or ET-1 in serum-free MEM at $37^{\circ} \mathrm{C}$ for $20 \mathrm{~h}$. $\left[{ }^{3} \mathrm{H}\right]-$ Thymidine $(0.5 \mu \mathrm{Ci})$ was then added and further incubated for $4 \mathrm{~h}$. After completion, cells were rinsed three times with ice-cold PBS, and incubated with $5 \%$ trichloroacetic acid (TCA) on ice for $20 \mathrm{~min}$. After washing twice with ice-cold 5\% TCA, cells were solubilized in $0.5 \mathrm{~N}$ $\mathrm{NaOH}$. An aliquot of TCA-insoluble materials was neutralized with 0.5 $\mathrm{N} \mathrm{HCl}$, and radioactivity was determined by a liquid scintillation counter (Model 460CD; Packard Instrument Co. Inc., Meriden, CO).

cGMP measurement. Cardiac fibroblasts $\left(4 \times 10^{4}\right.$ cells per well $)$ were preincubated in $1 \mathrm{ml}$ serum-free MEM containing $0.5 \mathrm{mM}$ IBMX for $30 \mathrm{~min}$ at $37^{\circ} \mathrm{C}$, and then stimulated with ANP, BNP and SNP at $37^{\circ} \mathrm{C}$ for $30 \mathrm{~min}$. After aspiration of the medium, the reaction was terminated by adding $100 \mu \mathrm{l}$ of ice-cold $1 \mathrm{~N} \mathrm{HCl}$. After neutralization with $1 \mathrm{~N} \mathrm{NaOH}$, concentrations of intracellular cGMP were determined by radioimmunoassay kit (Amersham International. Bucks, UK).

Statistical analyses. One way ANOVA followed by the multiple comparison methods of Scheffe was used for statistical analyses. $P$ $<0.05$ was considered significant. Values were expressed as mean \pm SEM.

\section{Results}

Characterization of rat cardiac fibroblasts in culture. Immunocytochemical study revealed that all of cultured cells exhibited positive staining for vimentin (Fig. $1 A$ ) and negative staining for either factor VIII (Fig. $1 B$ ) or $\alpha$-actin (Fig. $1 C$ ), indicating that there was no contamination of our rat cardiac fibroblast culture with endothelial cells or myocytes.

Upregulation of ppET-1 gene expression by ANG II. Northern blot analysis of total RNA from cultured rat cardiac fibroblasts with cDNA for rat ppET-1 as a probe revealed a distinct band corresponding to the size $(2.3 \mathrm{~kb})$ of rat ppET-1 mRNA. ANG II $\left(10^{-8} \mathrm{M}\right)$ transiently (30 min) increased steady-state levels of ppET-1 mRNA which then returned to the basal level after $2 \mathrm{~h}$ (Fig. 2). Expression of $c$-fos mRNA was also transiently ( $30 \mathrm{~min}$ ) induced by ANG II and disappeared thereafter. The ANG II-induced ppET-1 mRNA expression ( $30 \mathrm{~min}$ ) was dose-dependent $\left(10^{-12}-10^{-8} \mathrm{M}\right)$ (Fig. 3); the maximum induction $(786 \pm 86 \%, n=4)$ was induced with $10^{-8} \mathrm{M}$.

ppET-1 mRNA expression by ET-1 and ANG II is mediated through $E T_{A}$ receptor. To determine whether ppET-1 mRNA expression induced by ET-1 and ANG II is mediated via $\mathrm{ET}_{\mathrm{A}}$ receptor subtype in cardiac fibroblasts, an $\mathrm{ET}_{\mathrm{A}}$ receptor antagonist (BQ123) was used. As shown in Fig. 4, upregulation of ppET-1 mRNA induced by both ET-1 $\left(10^{-8} \mathrm{M}\right)$ and ANG II $\left(10^{-8} \mathrm{M}\right)$ was similarly blocked by BQ123 $\left(10^{-5} \mathrm{M}\right)$. 
$\mathbf{A}$

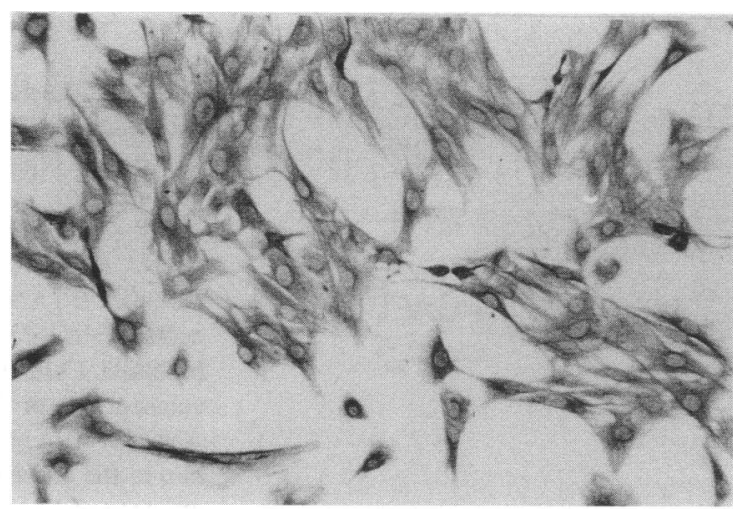

B

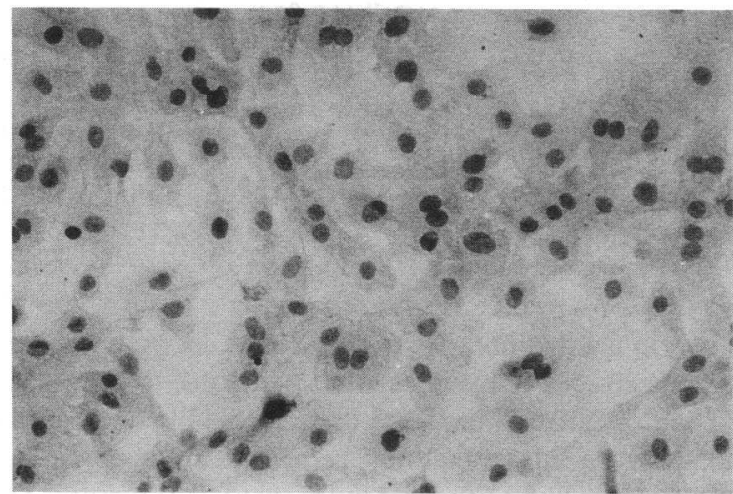

C

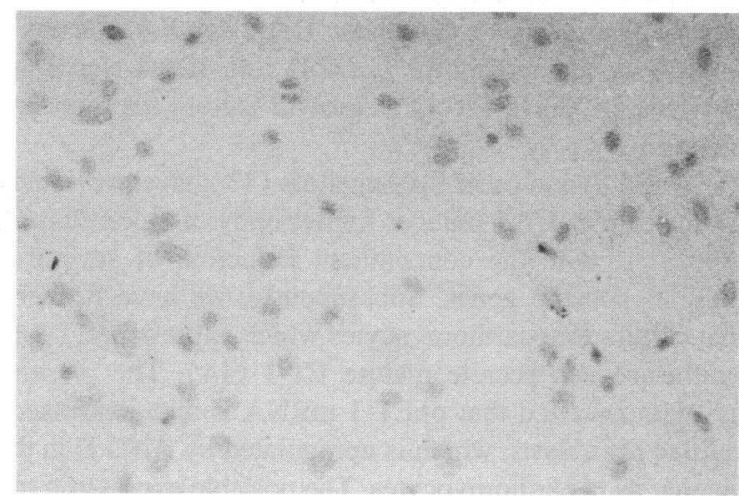

Figure 1. Photomicrographs of cultured neonatal rat cardiac fibroblasts immunocytochemically stained with antibody for vimentin $(A)$, factor VIII $(B)$, and sarcomeric $\alpha$-actin $(C)$. Original magnification $\times 200$.

DNA synthesis by ANG II and ET-1 is mediated through $E T_{A}$ receptor. Both ANG II $\left(10^{-8} \mathrm{M}\right)$ and ET-1 $\left(10^{-8} \mathrm{M}\right)$ significantly $(P<0.05)$ stimulated $\left[{ }^{3} \mathrm{H}\right]$ thymidine incorporation into cardiac fibroblasts by $124 \pm 6.4 \%(n=4)$ and $133 \pm 10 \%(n=4)$ over control, respectively. The stimulatory effects on DNA synthesis by ET-1 and ANG II were similarly and significantly $(P<0.05)$ inhibited by BQ123 $\left(10^{-5} \mathrm{M}\right)$ (Fig. 5); BQ123 alone had no effect on basal $\left[{ }^{3} \mathrm{H}\right]$ thymidine uptake.

Natriuretic peptides, cGMP and SNP inhibit ANG II-induced ppET-1 mRNA expression and DNA synthesis. ANP $\left(10^{-7} \mathrm{M}\right)$ and BNP $\left(10^{-7} \mathrm{M}\right)$ similarly inhibited the ANG II $\left(10^{-8} \mathrm{M}\right)$-stimulated ppET-1 mRNA expression by $45.0 \pm 2.7 \%$ $(n=4)$, and $36.7 \pm 2.4 \%(n=4)$, respectively (Fig. 6, $A$ and $B)$. Similarly, 8-bromo-cGMP $\left(10^{-3} \mathrm{M}\right)$ and $\operatorname{SNP}\left(10^{-3} \mathrm{M}\right)$

\section{$\begin{array}{llllllll}0 & 5 & 10 & 15 & 30 & 60 & 120 & \text { Time }(\mathrm{min})\end{array}$}

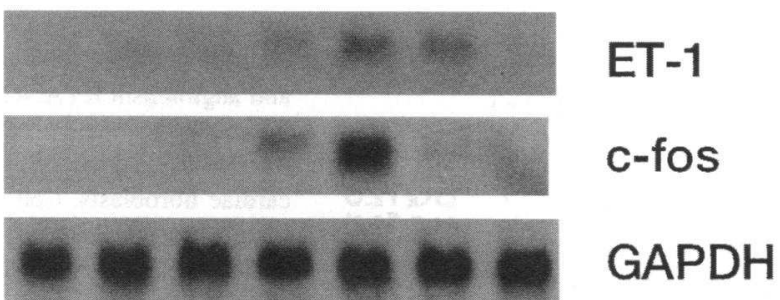

Figure 2. Effect of angiotensin II (ANG II) on endothelin-1 (ET-1) and c-fos mRNA expression in neonatal rat cardiac fibroblasts as a function of time. Cells were incubated with ANG II $\left(10^{-8} \mathrm{M}\right)$ for the indicated times. Northern blot hybridization ( $7 \mu \mathrm{g}$ of total RNA/each lane) was performed using ${ }^{32} \mathrm{P}$-labeled rat ppET-1, human $c$-fos or human glyceraldehyde-3-phosphate dehydrogenase (GAPDH) cDNA as probes. Exposure time: $72 \mathrm{~h}$ for ET-1 and $c$-fos and $24 \mathrm{~h}$ for GAPDH.

inhibited the ANG II-stimulated ppET-1 mRNA expression by $55.8 \pm 3.0 \%(n=4)$ and $41 \pm 0.4 \%(n=3)$, respectively (Fig. $7, A$ and $B$ ).

We next examined whether natriuretic peptides inhibit DNA synthesis stimulated by ANG II and ET-1 in rat cardiac fibroblasts (Fig. 8). The ANG II $\left(10^{-8} \mathrm{M}\right)$-stimulated $\left[{ }^{3} \mathrm{H}\right]-$ thymidine incorporation was dose-dependently inhibited by $\mathrm{ANP}$ and $\mathrm{BNP}$ with the approximate $\mathrm{IC}_{50}$ values of $2.5 \times 10^{-9}$ $\mathrm{M}$ and $4 \times 10^{-11} \mathrm{M}$, respectively (Fig. $8 \mathrm{~A}$ ). Likewise, the ET$1\left(10^{-8} \mathrm{M}\right)$-stimulated $\left[{ }^{3} \mathrm{H}\right]$ thymidine incorporation was dosedependently inhibited by ANP and BNP with $\mathrm{IC}_{50}$ values of 3 $\times 10^{-10} \mathrm{M}$ and $4 \times 10^{-12} \mathrm{M}$, respectively (Fig. $8 \mathrm{~B}$ ). SNP $\left(10^{-3} \mathrm{M}\right)$ similarly inhibited $\left[{ }^{3} \mathrm{H}\right]$ thymidine incorporation stimulated by ANG II $\left(10^{-8} \mathrm{M}\right)$ (data not shown).

Production of cGMP by natriuretic peptides and SNP. Both ANP and BNP dose-dependently $\left(10^{-9}-10^{-6} \mathrm{M}\right)$ and equipotently stimulated intracellular cGMP formation in rat cardiac fibroblasts after $30 \mathrm{~min}$ of incubation (Fig. 9); the maximal effects $(\sim 73$-fold increase over control) were induced with $10^{-6} \mathrm{M}$ and the approximate $\mathrm{EC}_{50}$ values were $3 \times 10^{-7} \mathrm{M}$. SNP $\left(10^{-3} \mathrm{M}\right)$ increased cGMP production by 74 -fold over control by $30 \mathrm{~min}$ (data not shown).

\section{Discussion}

In the present study, we demonstrate that (1) cardiac fibroblasts express ppET-1 mRNA, which is similarly upregulated by ET-

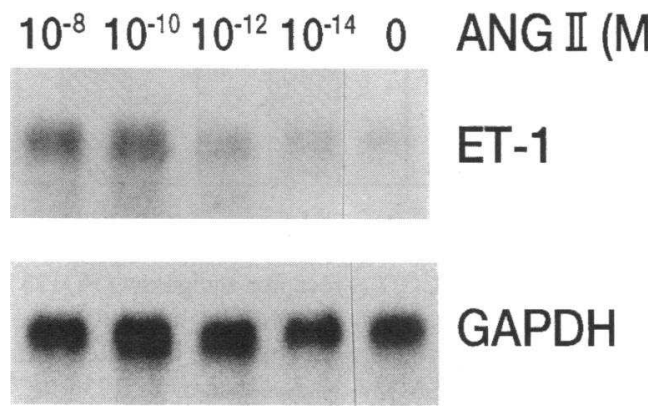

Figure 3. Dose-response effect of angiotensin II (ANG II) on endothelin-1 (ET-1) mRNA expression in rat cardiac fibroblasts. Cells were incubated with various doses $\left(10^{-14}-10^{-8} \mathrm{M}\right)$ of ANG II for $30 \mathrm{~min}$. Northern blot analysis was performed in the same manner as in Fig. 2. 


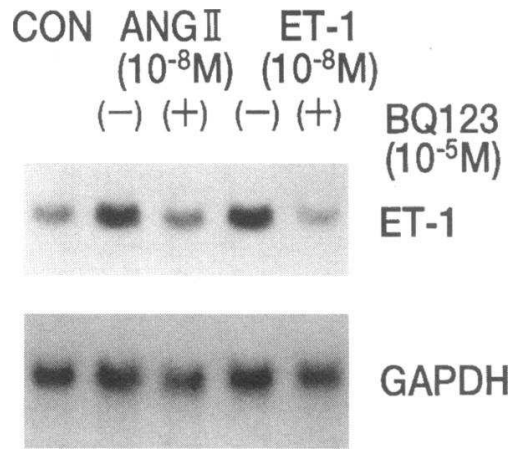

Figure 4. Effect of an endothelin A $\left(\mathrm{ET}_{\mathrm{A}}\right)$ receptor antagonist (BQ123) on endothelin-1 (ET-1) and angiotensin II (ANG II)-induced ppET-1 mRNA in cultured rat cardiac fibroblasts. Cells were incubated with ET$1\left(10^{-8} \mathrm{M}\right)$ and ANG II $\left(10^{-8} \mathrm{M}\right)$ with or without BQ123 $\left(10^{-5} \mathrm{M}\right)$ for 30 min. Northern blot hybridization was performed essentially in the same manner as in

Fig. 2.

1 and ANG II, (2) both ET-1 and ANG II stimulate DNA synthesis of cardiac fibroblasts, (3) an $\mathrm{ET}_{\mathrm{A}}$ receptor antagonist blocks both ppET-1 mRNA and DNA synthesis stimulated by ET-1 and ANG II, and (4) ANP and BNP as well as 8-bromocGMP and SNP inhibit ANG II-stimulated ppET-1 mRNA expression and DNA synthesis of cardiac fibroblasts.

Accumulation of collagen fibrils occurs within the extracellular matrix and around the intramyocardial coronary arteries of hypertrophied myocardium $(3,22,23)$. The proliferation of cardiac fibroblasts, the principal regulatory cells in the remodeling of the cardiac interstitium, may be regulated not only by mechanical factors such as pressure and volume overload, but also by neurohumoral factors and/or local growth factors (24). It has been recently shown that ANG II stimulates cell proliferation (7) and induces expression of several extracellular matrix

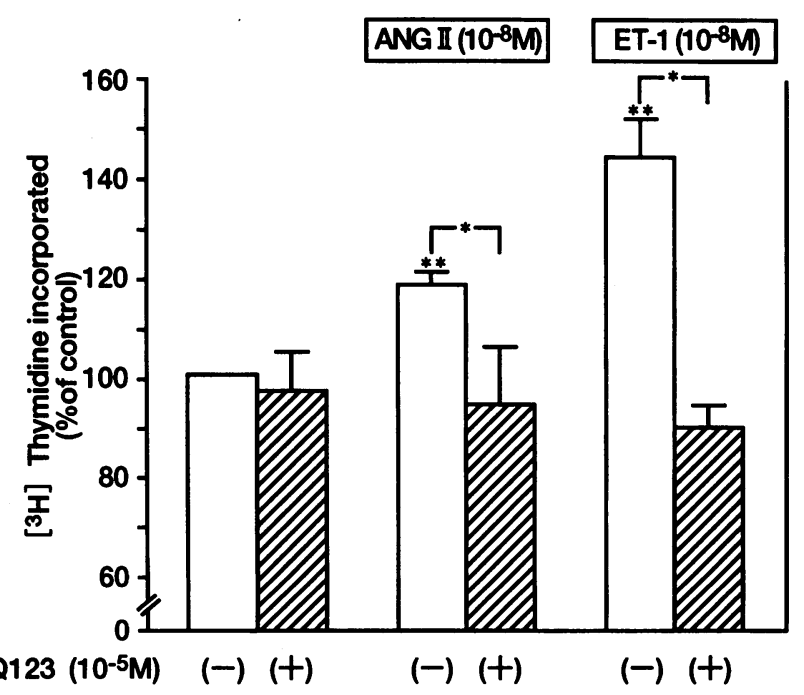

Figure 5. Effect of an endothelin $\mathrm{A}\left(\mathrm{ET}_{\mathrm{A}}\right)$ receptor antagonist (BQ123) on endothelin-1 (ET-1)- and angiotensin II (ANG II)-induced DNA synthesis in cultured rat cardiac fibroblasts. Cells were incubated with ET-1 $\left(10^{-8} \mathrm{M}\right)$ and ANG II $\left(10^{-8} \mathrm{M}\right)$ in the presence of BQ123 $\left(10^{-5}\right.$ M) for $24 \mathrm{~h}$. DNA synthesis was assessed by incorporation of $\left[{ }^{3} \mathrm{H}\right]-$ thymidine into the cells; basal $\left[{ }^{3} \mathrm{H}\right]$ thymidine uptake was $1859 \pm 108$ cpm $(n=4)$. Each column represents the mean of four cultures; bars show SEM. Significantly different $(P<0.05)(*)$ from BQ123-treated cells, and $(* *)$ from control cells.
A

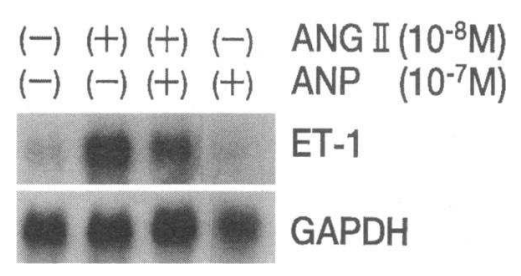

B

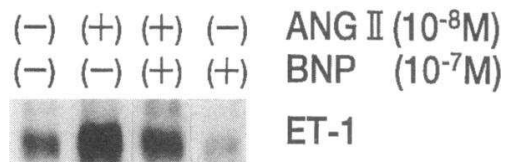

노 natriuretic peptide (ANP) and brain natriuretic peptide (BNP) on endothelin-1 (ET-1) mRNA induction by angiotensin II (ANG II) in neonatal rat cardiac fibroblasts. Cells were incubated with or without ANG II $\left(10^{-8} \mathrm{M}\right)$ for 30 $\min$ in the absence and presence of $(A)$ ANP $\left(10^{-7} \mathrm{M}\right)$ and $(B)$ BNP $\left(10^{-7} \mathrm{M}\right)$. Northern blot hybridization ( $7 \mu \mathrm{g}$ of total RNA/each lane) same manner as in Fig. 2.
Figure 6. Effects of atrial was performed in the

genes in cardiac fibroblasts (8). These data suggest that ANG II-induced cardiac hypertrophy is partly due to increased proliferation of cardiac fibroblasts accompanied by increased formation of extracellular matrix. The present study confirmed these observations and further extended that ET-1, a potent vasoconstrictor peptide, also stimulates DNA synthesis of rat cardiac fibroblasts, suggesting the possible role of two vasoconstrictor peptides (ANG II, ET-1) as growth factors for myocardial remodeling.

We (11) and other investigators (13) have previously demonstrated that ET-1 induces hypertrophy of cultured rat cardiomyocytes, with the concomitant induction of several cardiac muscles specific genes. Subsequently, we have further shown that cultured rat cardiomyocytes which express ppET-1 mRNA, synthesize and secrete mature ET-1 (14). The present study has demonstrated that ppET-1 mRNA is also expressed by rat cardiac fibroblasts, which is upregulated by ANG II in the same manner as in cardiomyocytes. The possible expression of ppET-

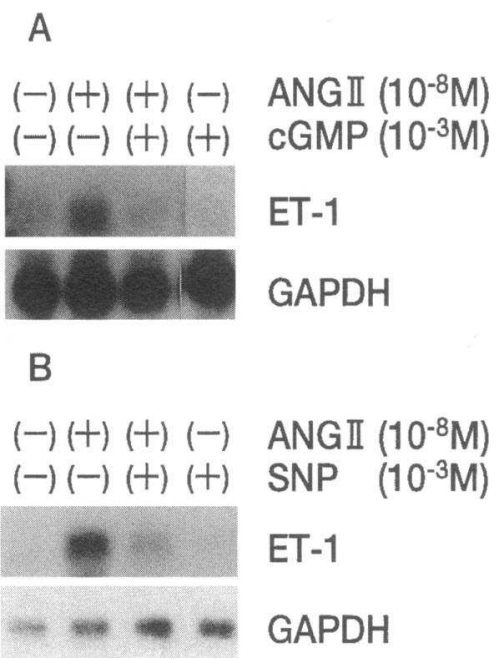

Figure 7. Effects of 8-bromo-cyclic GMP (cGMP) and sodium nitroprusside (SNP) on endothelin-1 (ET-1) mRNA induction by angiotensin II (ANG II) in neonatal rat cardiac fibroblasts. Cells were incubated with or without ANG II $\left(10^{-8} \mathrm{M}\right)$ for $30 \mathrm{~min}$ in the absence and presence of $(A) 8$ bromo-cGMP $\left(10^{-3} \mathrm{M}\right)$ and $(B) \operatorname{SNP}\left(10^{-3} \mathrm{M}\right)$ $\left(10^{-5} \mathrm{M}\right)$. Northern blot hybridization ( $7 \mu \mathrm{g}$ of total RNA/each lane) was performed in the same manner as in Fig. 2. 
A ANGII (10-8 M)

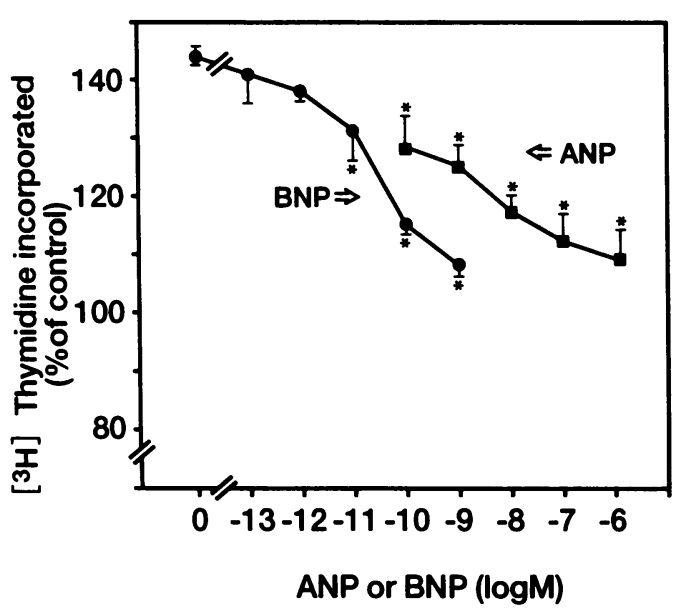

B $\quad$ ET-1 (10-8M)

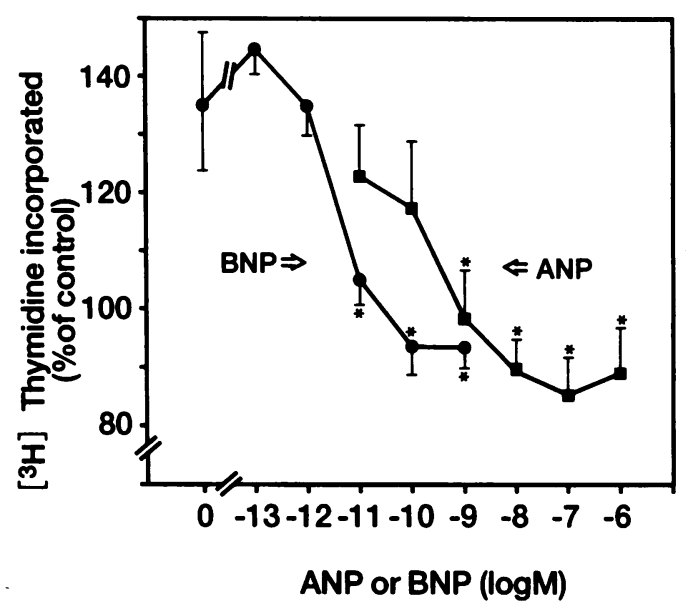

Figure 8. Effects of atrial natriuretic peptide (ANP) and brain natriuretic peptide (BNP) on DNA synthesis stimulated by angiotensin II (ANG II) and endothelin-1 (ET-1) of neonatal rat cardiac fibroblasts. Cells were incubated with $(A)$ ANG II $\left(10^{-8} \mathrm{M}\right)$ and $(B)$ ET-1 $\left(10^{-8} \mathrm{M}\right)$ in the absence and presence of various doses $\left(10^{-13}-10^{-6} \mathrm{M}\right)$ of ANP $(\square)$ and BNP $(\bullet)$ for $24 \mathrm{~h}$. DNA synthesis was assessed by incorporation of $\left[{ }^{3} \mathrm{H}\right]$ thymidine into the cells; basal $\left[{ }^{3} \mathrm{H}\right.$ ] thymidine uptake was $1180 \pm 54 \mathrm{cpm}(n=4)$. Each point represents the mean of 4 cultures; bars show SEM. $*$ Statistically significant from the ANG II-treated cells without natriuretic peptides $(P<0.05)$.

1 by cells other than fibroblasts seems unlikely, because our cardiac fibroblast cultures were not contaminated with either endothelial cells or myocytes as evaluated by immunocytochemical studies using anti-factor VIII or anti-sarcomeric $\alpha$ actin antibody, respectively. In contrast to the relatively late induction (2-4 h) of ET-1 mRNA in endothelial cells (25), ANG II-induced ET-1 mRNA expression peaked at very early time point ( $30 \mathrm{~min}$ ) in cardiac fibroblasts. This time course was almost comparable to that of c-fos mRNA, one of the early immediate protooncogenes. Such an early induction of ET-1

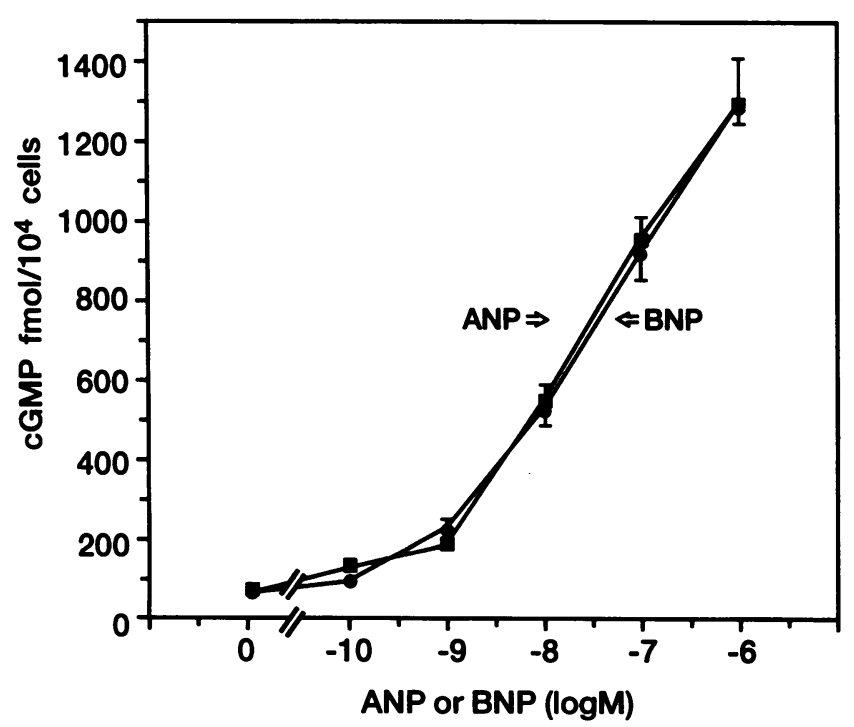

Figure 9. Effects of atrial natriuretic peptide (ANP) and brain natriuretic peptide (BNP) on intracellular cGMP formation in cardiac fibroblasts. Cardiac fibroblasts were incubated with or without various doses of ANP ( $\bullet$ ) and BNP (•) for $30 \mathrm{~min}$ in the presence of $0.5 \mathrm{mM} \mathrm{IBMX}$. Each point represents the means of six cultures; bars show SEM.
mRNA by ANG II has been also observed in other cell types, including vascular smooth muscle cells (26) and cardiomyocytes (14). The concomitant expression of ppET-1 and c-fos mRNA in cardiac fibroblasts by ANG II is likely to be mediated by activation of protein kinase $\mathrm{C}$, resulting from receptor-mediated phosphoinositol breakdown as has been suggested in cardiomyocytes (11) and vascular smooth muscle cells (27).

In this study, exogenous ET-1 upregulated ppET-1 mRNA expression and stimulated DNA synthesis in cardiac fibroblasts, whose effects were completely inhibited by an $\mathrm{ET}_{\mathrm{A}}$ receptor antagonist (BQ123). These data suggest that endogenous ET1 may positively regulate its own gene expression and cell growth through $\mathrm{ET}_{\mathrm{A}}$ receptors as an autocrine/paracrine factor. Likewise, the ANG II-induced ppET-1 mRNA expression and DNA synthesis in cardiac fibroblasts, were inhibited by BQ123. These data are compatible with those of our previous study using rat cardiomyocytes in which an $\mathrm{ET}_{\mathrm{A}}$ receptor antagonist partially blocked ppET-1 mRNA expression and protein synthesis stimulated by ANG II $(28,29)$. Taken together, it is suggested that ANG II-induced proliferation of cardiac fibroblasts is partly mediated by endogenous ET-1 produced by both cardiomyocytes and cardiac fibroblasts in an autocrine/paracrine manner.

The present study clearly demonstrated that cardiac natriuretic peptides (ANP, BNP) inhibited DNA synthesis as well as ppET-1 mRNA expression stimulated by ET-1 and ANG II in rat cardiac fibroblasts. These data suggest that natriuretic peptides have a direct inhibitory effect on proliferation of cardiac fibroblasts. We have previously reported that cardiac fibroblasts possess abundant natriuretic peptide receptors coupled to guanylate cyclase, whose functions remained unsettled at that time (30). There exist at least three receptor subtypes for natriuretic peptides known to date, namely ANP-A receptor (GC-A), ANP-B receptor (GC-B), and clearance (C) receptor (15). Both GC-A and GC-B are single transmenbrane receptors containing an extra-cellular binding domain and an intracellular 
guanylate cyclase domain. The GC-A receptor responds similarly to ANP and BNP, while the GC-B receptor is preferentially activated by CNP (31). In contrast, C-receptor which lacks the intracellular guanylate cyclase domain, shows non-selective binding affinity for three natriuretic peptides, and has been suggested to mediate sequestration and clearance of circulating natriuretic peptides.

Since both, ANP and BNP equipotently stimulated intracellular cGMP formation in cardiac fibroblasts as demonstrated in this study, it is most likely that natriuretic peptides activate GCA receptors in cardiac fibroblasts. In this study, SNP which activates soluble guanylate cyclase as well as a membranepermeable derivative 8-bromo-cGMP, similarly inhibited the ANG II-induced ET-1 expression and DNA synthesis in the same fashion as did natriuretic peptides. Taken together, it is suggested the intracellular cGMP plays a major mediator role in the mechanism of natriuretic peptides-induced inhibition of ppET-1 mRNA expression and DNA synthesis. It has recently been reported that ANP inhibits ET-1-induced activation of mitogen-activated protein (MAP) kinase and translocation of PKC in rat mesangial cells (32). Therefore, one might speculate that cGMP-dependent protein kinase may affect these protein kinases, thereby leading to inhibition of cardiac fibroblasts proliferation (33).

In the present study, however, the inhibitory effect of BNP on DNA synthesis was about two orders more potent than that of ANP, whereas cGMP production by these two natriuretic peptides was almost equipotent. Such discrepancy may be accounted for by the possible involvement of pathways other than cGMP in natriuretic peptides-induced inhibition of cardiac fibroblast proliferation. It is noteworthy that $\mathrm{C}$-receptor is also involved in inhibition of mitogenesis and proliferation of cultured rat vascular smooth muscle cells via cGMP-independent mechanism. Since rat cardiomyocytes contain both GC-A and C-receptor (34), the more potent inhibition by BNP on DNA synthesis in rat cardiomyocytes may be mediated via $\mathrm{C}$-receptor by the cGMP-independent mechanism. However, the signal transduction of $\mathrm{C}$-receptor in relation to mitogenesis remains to be determined.

It should be also noted that ANP and BNP are both cardiac hormones synthesized by and secreted from cardiomyocytes located very close to cardiac fibroblasts. Therefore, it is possible to speculate that natriuretic peptides may exert their growthinhibitory effects on cardiac fibroblasts in a paracrine manner to counteract growth-promoting effects by two vasoconstrictors, (ANG II and ET-1), via a negative feedback loop.

In summary, our study has demonstrated that endogenous ET-1 induced by ANG II in neonatal rat cardiac fibroblasts is an autocrine/paracrine growth factor, and that natriuretic peptides inhibit the proliferation of cardiac fibroblasts stimulated by ET1 and ANG II. We propose the possible existence of a close interaction between cardiac ET-1 and natriuretic peptides (ANP, BNP), constituting a positive and negative regulatory system for cardiac remodeling.

\section{Acknowledgments}

We thank Dr. T. Masaki and Dr. K. Webster for providing the cDNAs for rat ppET-1 and GAPDH, respectively, and Dr. M. Yano (Central Research Laboratories, Banyu Pharmaceutical Co. Ltd.) for the BQ123.

This study was supported in part by Grants-in-Aid for Scientific
Research from the Ministry of Education, Science and Culture, and the Ministry of Health and Welfare, Japan, and by a grant from the Study Group of Molecular Cardiology, Tokyo.

\section{References}

1. Zak, R. 1973. Cell proliferation during cardiac growth. Am. J. Cardiol. 31:211-219.

2. Frank, J. S., and G. A. Langer. 1974. The myocardial interstitium: Its structure and its role in ionic exchange. J. Cell Biol. 60:586-601.

3. Weber, K. T., and C. G. Brilla. 1991. Pathological hypertrophy and cardiac interstitium: fibrosis and the renin-angiotensin-aldosterone system. Circulation. 83:1849-1865.

4. Brilla, C. G., J. S. Janicki, and K. T. Weber. 1991. Cardioreparative effects of lisinopril in rats with genetic hypertension and left ventricular hypertrophy. Circulation. 83:1771-1779.

5. Baker, K. M., M. I. Chernin, S. K. Wixson, and J. F. Aceto. 1990. Reninangiotensin system involvement in pressure-overload cardiac hypertrophy in rats. Am. J. Physiol. 259:H324-H332.

6. Dotal, D. E. 1992. Angiotensin II stimulation of left ventricular hypertrophy in adult rat heart. Mediation by the $\mathrm{AT}_{1}$ receptor. Am. J. Hypertens. 5:276-280.

7. Schorb, W., G. W. Booz, D. E. Dostal, M. K. Conrad, K. C. Chang, and K. M. Baker. 1993. Angiotensin II is mitogenic in neonatal rat cardiac fibroblasts. Circ. Res. 72:1245-1254.

8. Villarreal, F. J., N. N. Kim, G. D. Ungab, M. P. Printz, and W. H. Dillmann. 1993. Identification of functional angiotensin II receptors on rat cardiac fibroblasts. Circulation. 88:2849-2861.

9. Aceto, J. F., and K. M. Baker. 1990. [Sar1 ] angiotensin II receptor-mediated stimulation of protein synthesis in chick heart cells. Am. J. Physiol. 258:H806H813.

10. Sadoshima, J., Y. Xu, H. S. Slayter, and S. Izumo. 1993. Autocrine release of angiotensin II mediates stretch-induced hypertrophy of cardiac myocytes in vitro. Cell. 75:977-984.

11. Ito, H., Y. Hirata, M. Hiroe, M. Tsujino, S. Adachi, T. Takamoto, M. Nitta, K. Taniguchi, and F. Marumo. 1991. Endothelin-1 induces hypertrophy with enhanced expression of muscle-specific genes in cultured neonatal rat cardiomyocytes. Circ. Res. 69:209-215.

12. Suzuki, T., H. Hoshi, and Y. Mitsui. 1990. Endothelin stimulates hypertrophy and contractility of neonatal rat cardiac myocytes in a serum-free medium. FEBS (Fed. Eur. Biochem. Soc.) Lett. 268:149-151.

13. Shubeita, H. E., P. M. McDonough, A. N. Harris, K. U. Knowlton, C. C. Glembotski, J. H. Brown, and K. R. Chien. 1990. Endothelin induction of inositol phospholipid hydrolysis, sarcomere assembly, and cardiac gene expression in ventricular myocytes. A paracrine mechanism for myocardial cell hypertrophy. J. Biol. Chem. 265:20555-20562.

14. Ito, H., Y. Hirata, S. Adachi, M. Tanaka, M. Tsujino, A. Koike, A. Nogami, F. Marumo, and M. Hiroe. 1993. Endothelin-1 is an autocrine/paracrine factor in the mechanism of angiotensin II-induced hypertrophy in cultures rat cardiomyocytes. J. Clin. Invest. 92:398-403.

15. Koller, K. J., and D. V. Goeddel. 1992. Molecular biology of the natriuretic peptides and their receptors. Circulation. 86:1081-1088.

16. Itoh, H., R. E. Pratt, M. Ohno, and V. J. Dzau. 1992. Atrial natriuretic polypeptide as a novel antigrowth factor of endothelial cells. Hypertension. 19:758-761.

17. Emori, T., H. Hirata, T. Imai, S. Eguchi, K. Kanno, and F. Marumo. 1993. Cellular mechanism of natriuretic peptides-induced inhibition of endothlin1 biosynthesis in rat endothelial cells. Endocrinology. 133:2474-2480.

18. Ihara, M., K. Noguchi, t. Saeki, T. Fukuroda, S. Tsuchida, S. Kimura, T Fukami, K. Ishikawa, M. Nishikabe, and M. Yano. 1992. Biological profiles of highly potent novel endothelin antagonists selective for the $\mathrm{ET}_{\mathrm{A}}$ receptor. Life Sciences. 50:247-255.

19. Ito, H., M. Hiroe, Y. Hirata, M. Tsujino, S. Adachi, M. Shichiri, A. Koike, A. Nogami, and F. Marumo. 1993. Insulin-like growth factor-I induces hypertrophy with enhanced expression of muscle specific genes in cultured rat cardiomyocytes. Circulation. 87:1715-1721.

20. Chirgwin, J. M., A. E. Przybyla, R. J. MacDonald, and W. J. Rutter. 1979. Isolation of biologically active ribonucleic acid from sources enriched in ribonuclease. Biochemistry. 18:5294-5299.

21. Feinberg, A. P., and B. A. Vogelstein. 1983. Technique for radiolabeling DNA restriction endonuclease fragments to high specific activity. Anal. Biochem. 132:6-13.

22. Julil, J. E., C. W. Dowering, J. S. Jankcki, R. Pick, W. A. Clark, and K. T. Weber. 1989. Fibrillar collagen and myocardial stiffness in the intact hypertrophied rat left ventricle. Circ. Res. 64:1041-1050.

23. Anversa, P., G. Olivetti, M. Melissari, and A. V. Loud. 1979. Morphometric study of myocardial hypertrophy induced by abdominal aortic stenosis. Lab. Invest. 40:341-349. 
24. Weber, K. T., W. A. Clark, J. S. Janicki, and S. G. Schroff. 1987. Physiologic versus pathologic hypertrophy and the pressure-overload myocardium. $J$. Cardiovasc. Pharmacol. 10:S32-S49.

25. Yanagisawa, M., H. Kurihara, S. Kimura, Y. Tomobe, M. Kobayashi, Y. Mitsui, Y. Yazaki, K. Goto, and T. Masaki. 1988. A novel potent vasoconstrictor peptide produced by vascular endothelial cells. Nature (Lond.). 332:411-415.

26. Hahn, A. W., T. J. Resink, B. T. Scott, J. Powell, Y. Dohi, and F. R. Buhler. 1990. Stimulation of endothelin mRNA and secretion in rat vascular smooth muscle cells: a novel autocrine function. Cell Regul. 1:649-659.

27. Araki,S., Y. Kawahara, K. Kariya, M. Sunako, H. Fukuzaki, Y. Takai. 1989. Stimulation of phospholipase C-mediated hydrolysis of phosphoinositides by endothelin in cultured rabbit aortic smooth muscle cells. Biochem. Biophys. Res. Commun. 159:1027-1029.

28. Inoue, A., M. Yanagisawa, Y. Takuwa, Y. Mitsui, M. Kobayashi, and T Masaki. 1989. The human preproendothelin-1 gene. Complete nucleotide sequence and regulation of expression. J. Biol. Chem. 264:14954-14959.

29. Hirata, Y., H. Yoshimi, S. Takaichi, M. Yanagisawa, and T. Masaki. 1988.
Binding and receptor down-regulation of a novel vasoconstrictor endothelin in cultured rat vascular smooth muscle cells. FEBS (Fed. Eur. Biochem. Soc.) Lett. 239:13-17.

30. Hirata, Y. M. Tomita, S. Takata, and I. Inoue. 1985. Specific binding sites for atrial natriuretic peptide (ANP) in cultured mesenchymal nonmyocardial cells from rat heart. Biochem. Biophys. Res. Commun. 131:222-229.

31. Chang, M., D. G. Lowe, M. Lewis, R. Hellmiss, and V. Goeddel. 1989 Differential activation by atrial and brain natriuretic peptides of two different receptor guanylate cyclases. Nature (Lond.). 341:68-71.

32. Sugimoto, T., R. Kikkawa, M. Haneda, and Y. Shigeta. 1993. Atrial natriuretic peptide inhibits endothelin-1-induced activation of mitogen-activated protein kinase in cultured rat mesangial cells. Biochem. Biophys. Res. Commun. 195:72-78.

33. Hisa, H., Y. Tomura, T. Yamagata, and S. Satoh. 1992. Atrial natriuretic peptide suppresses renal vasoconstriction induced by angiotensin II and norepinephrine in dogs. Eur. J. Pharmacol. 222:265-271.

34. Nunez, D. J., M. C. Dickson, and M. J. Brown. 1992. Natriuretic peptide receptor mRNAs in the rat and human heart. J. Clin. Invest. 90:1966-1971. 